\title{
Advanced Gastric Large Cell Neuroendocrine Carcinoma
}

National Cancer Institute

\section{Source}

National Cancer Institute. Advanced Gastric Large Cell Neuroendocrine Carcinoma. NCI

Thesaurus. Code C156684.

A gastric large cell neuroendocrine carcinoma that has spread extensively to other anatomic sites or is no longer responding to treatment. 